\title{
Thermo-alkali-stable catalases from newly isolated Bacillus sp. for the treatment and recycling of textile bleaching effluents
}

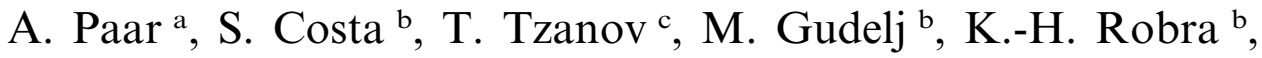 \\ A. Cavaco-Paulo ${ }^{c}$, G.M. Gübitz ${ }^{\text {a,b,* }}$ \\ a Sucher\&Holzer GmbH, Alberstraße 4, A-8010 Graz, Austria \\ ${ }^{\mathrm{b}}$ Department of Environmental Biotechnology, Graz University of Technology, Petersgasse 12, A-8010 Graz, Austria \\ ${ }^{\mathrm{c}}$ Department of Textile Engineering, University of Minho, 4800 Guimaraes, Portugal
}

Received 26 June 2000; received in revised form 18 December 2000; accepted 3 January 2001

\begin{abstract}
Three thermoalkaliphilic bacteria, which were grown at $\mathrm{pH} 9.3-10$ and $60-65{ }^{\circ} \mathrm{C}$ were isolated out of a textile wastewater drain. The unknown micro-organisms were identified as thermoalkaliphilic Bacillus sp. Growth conditions were studied and catalase activities and stabilities compared. Catalases from Bacillus SF showed high stabilities at $60{ }^{\circ} \mathrm{C}$ and $\mathrm{pH} 9\left(t_{1 / 2}=38 \mathrm{~h}\right)$ and thus this strain was chosen for further investigations, such as electron microscopy, immobilization of catalase and hydrogen peroxide degradation studies. Degradation of hydrogen peroxide with an immobilized catalase from Bacillus SF enabled the reuse of the water for the dyeing process. In contrast, application of the free enzyme for treatment of bleaching effluents, caused interaction between the denaturated protein and the dye, resulting in reduced dye uptake, and a higher color difference of $1.3 \Delta E^{*}$ of dyed fabrics compared to $0.9 \Delta E^{*}$ when using the immobilized enzyme. (C) 2001 Elsevier Science B.V. All rights reserved.
\end{abstract}

Keywords: Hydrogen peroxide; Catalases; Thermoalkaliphilic

\section{Introduction}

More than 1001 of water are currently consumed in the textile finishing industry for the processing of $1 \mathrm{~kg}$ of textiles (Hillenbrand, 1999).

\footnotetext{
* Corresponding author. Tel.: + 43-316-873-8312; fax: + 43-316-873-8815.

E-mail address: guebitz@ima.tu-graz.ac.at (G.M. Gübitz).
}

Particularly, textile bleaching is a water intensive process and thus, several methods have been suggested to degrade the bleaching agent hydrogen peroxide, which would allow recycling of the bleaching effluent in the dyeing process. However, the addition of chemicals such as sodium bisulphite or hydrosulphite for the reduction of $\mathrm{H}_{2} \mathrm{O}_{2}$ would lead to unfavorable high salt concentrations in the process.

Alternatively, catalases could be used for the 
conversion of $\mathrm{H}_{2} \mathrm{O}_{2}$ into oxygen and water. However, most commercial catalases would hardly withstand the conditions used during textile bleaching. Thus, new thermo-alkali-stable enzymes acting at temperatures above $60{ }^{\circ} \mathrm{C}$ and $\mathrm{pH}$ values above 9 are required.

Catalases have been studied for a longer time than any other type of enzymes, with the first biochemical characterization reported almost 100 years ago (Loew, 1901). Catalase was one of the first enzymes isolated in a high state of purity, and its crystallization from beef liver extracts ranked among the early triumphs of biochemistry (Sumner and Dounce, 1937). However, research on catalases is still going on and this class of enzymes continues to surprise us (Loewen et al., 2000). There is very little known about catalases from alkalithermophilic micro-organisms, although enormous progress has been made over the last few years in the research area of extremophiles (Krulwich and Guffanti, 1989; Berkeley and Goodacre, 1992; Nakamura et al., 1995; Michaudsoret et al., 1998). Some thermoalkalophilic Bacilli are known, (Sarkar and Upadhyay, 1993; Prowe et al., 1996; Rua et al., 1997; Takahashi et al., 2000), however, alkalithermophiles seem to be more abundant among anaerobic organisms (Wiegel, 1998).

Although catalase is one of the most effective biocatalysts in terms of turn-over number (Aebi, 1983), cost of enzyme for the degradation of $\mathrm{H}_{2} \mathrm{O}_{2}$ of bleaching effluents could be reduced by immobilization of the enzyme. Many industrial processes use immobilized enzymes and catalases have been immobilized on numerous carrier materials such as alumina, gelatine, polyacrylamide and hen egg shell (Chatterjee et al., 1990), artificial membranes (Gekas, 1986), and carbon materials (Horozova et al., 1997). Alumina pellets were chosen as a carrier material for catalases due to their stability at high $\mathrm{pH}$ and temperatures.

In this study, catalases from three newly isolated thermoalkophilic Bacillus sp. were immobilized on alumina pellets for the treatment of bleaching effluents. The reuse of the treated bleaching effluent for subsequent dyeing would lead to savings in overall water consumption of up to $50 \%$.

\section{Materials and methods}

\subsection{Screening}

Samples $(1 \mathrm{ml})$ of a wastewater drain from a textile finishing company were added to $50 \mathrm{ml}$ Standard I nutrient broth (Merck), buffered at $\mathrm{pH} 9.0$ or 10.0 , respectively, with $50 \mathrm{mM}$ $\mathrm{NaHCO}_{3} / \mathrm{Na}_{2} \mathrm{CO}_{3}$ and incubated in $100 \mathrm{ml}$ Erlenmeyer flasks with chicanes in a rotary shaker at $60{ }^{\circ} \mathrm{C}$ and $160 \mathrm{rpm}$. Growth was monitored under the microscope and micro-organisms $(1 \mathrm{ml})$ were transferred to fresh culture medium after 2 days. To isolate various strains, a dilution row was greased on Standard I nutrient agar (Merck) buffered with a $50 \mathrm{mM} \mathrm{NaHCO} / \mathrm{Na}_{2} \mathrm{CO}_{3}$ buffer, $\mathrm{pH}$ 10. Agar plates were incubated at $60{ }^{\circ} \mathrm{C}$ and constant humidity; isolated strains were deposited and identified by the German culture collection DSMZ (Braunschweig, Germany), including partial sequencing of $16 \mathrm{~S}$ rDNA.

\subsection{Fermentation}

Bacillus pallidus was grown in a medium consisting of $\left(\mathrm{g}^{-1}\right)$ glucose 3 , yeast extract (Merck) 5 , peptone from casein (Merck) 5 and $\mathrm{KH}_{2} \mathrm{PO}_{4} 1$ at $60{ }^{\circ} \mathrm{C}$ and $\mathrm{pH} 9.0$, buffered with $50 \mathrm{mM}$ $\mathrm{NaHCO}_{3} / \mathrm{Na}_{2} \mathrm{CO}_{3}$. Bacillus sp. LF was grown on $\left(\mathrm{g}^{-1}\right)$ glucose 5 , yeast extract 6 , peptone from casein (Merck) 6, and $\mathrm{KH}_{2} \mathrm{PO}_{4} 1$ at $60{ }^{\circ} \mathrm{C}$ and $\mathrm{pH} 9.3$, buffered with $50 \mathrm{mM} \mathrm{NaHCO} / \mathrm{Na}_{2} \mathrm{CO}_{3}$. The culture medium for Bacillus sp. SF consisted of $\left(\mathrm{g}^{-1}\right)$ yeast extract 8 , extract from meat (Merck) 8, and $\mathrm{KH}_{2} \mathrm{PO}_{4} 1$ at $65{ }^{\circ} \mathrm{C}$ and $\mathrm{pH} 10.0$, buffered with $50 \mathrm{mM} \mathrm{NaHCO} / \mathrm{Na}_{2} \mathrm{CO}_{3} .1 \%(\mathrm{v} / \mathrm{v})$ of a trace element solution containing $\left(\mathrm{mg}^{-1}\right)$ : $\mathrm{Na}_{2}$ EDTA $2500, \mathrm{ZnSO}_{4} \cdot 7 \mathrm{H}_{2} \mathrm{O} 100, \mathrm{MnCl}_{2} \cdot 4 \mathrm{H}_{2} \mathrm{O}$ $30, \mathrm{H}_{3} \mathrm{BO}_{3} 300, \mathrm{CaCl}_{2} \cdot 6 \mathrm{H}_{2} \mathrm{O} 200, \mathrm{CuCl}_{2} \cdot 2 \mathrm{H}_{2} \mathrm{O} 10$, $\mathrm{NiCl}_{2} \cdot 6 \mathrm{H}_{2} \mathrm{O} \quad 20, \quad \mathrm{Na}_{2} \mathrm{MoO}_{4} \cdot 2 \mathrm{H}_{2} \mathrm{O} \quad 900, \quad \mathrm{Na}_{2} \mathrm{SO}_{3}$ $\cdot 5 \mathrm{H}_{2} \mathrm{O} 30, \mathrm{FeSO}_{4} \cdot 7 \mathrm{H}_{2} \mathrm{O} 1000$, was added to all incubation mixtures.

Cells were harvested at the end of the exponential phase of growth, centrifuged $15 \mathrm{~min}$ at $3000 \times g$ and the pellet was suspended in the equal volume with $50 \mathrm{mM} \mathrm{NaH} \mathrm{PO}_{4}$ buffer $(\mathrm{pH}$ 7.0). Cell disruption was carried out using a sonification unit (Bandelin Sonoplus HD 70, Berlin, 
Germany) monitoring the progress under the microscope. Cell debris were removed by centrifugation $20 \mathrm{~min}$ at $6500 \times g$ and the remaining supernatant was stored at $4{ }^{\circ} \mathrm{C}$ and will be referred to as enzyme preparation.

\subsection{Electron microscopy}

Growing cells (exponential phase) were fixed by the addition of an equal volume of the fresh medium containing $8 \%(\mathrm{v} / \mathrm{v})$ glutaraldehyde to stabilize proteins. The mixture was kept at room temperature for $1 \mathrm{~h}$ and then at $4{ }^{\circ} \mathrm{C}$ overnight. Samples were sedimented by centrifugation $\left(1000 \times \mathrm{g}, 20 \mathrm{~min}, 20{ }^{\circ} \mathrm{C}\right)$, re-suspended in $0.1 \mathrm{M}$ sodium cacodylate buffer ( $\mathrm{pH} 7.2$ ) containing $4 \%$ (v/v) glutaraldehyde and kept for several days. The fixed samples were washed with 0.1 phosphate buffer ( $\mathrm{pH}$ 7.2), post-fixed with $\mathrm{OsO}_{4}$ at $4{ }^{\circ} \mathrm{C}$, dehydrated and embedded in epoxy resin. Sections stained with uranyl acetate and costained with lead citrate were analyzed in a transmission electron microscope (Philips CM 20 Analytical Electron Microscope).

\subsection{Catalase assay and enzyme stabilities}

Catalase activity was determined by monitoring the degradation of $\mathrm{H}_{2} \mathrm{O}_{2}$ spectrophotometrically at $240 \mathrm{~nm}$ as described previously (Aebi, 1983). The assay mixture contained $0.1 \mathrm{ml}$ of enzyme preparation, $1 \mathrm{ml}$ of a $26 \mathrm{mM} \mathrm{H}_{2} \mathrm{O}_{2}$ (Merck) stock solution and $0.9 \mathrm{ml}$ of buffer.

To determine catalase stability, $1 \mathrm{ml}$ of enzyme preparation was diluted with $9 \mathrm{ml}$ buffer in test tubes $\left(50 \mathrm{mM} \mathrm{NaHCO} 3 / \mathrm{Na}_{2} \mathrm{CO}_{3}\right.$ for $\mathrm{pH} 9$ and 10 , $50 \mathrm{mM} \mathrm{NaH} \mathrm{PO}_{4}$ for $\mathrm{pH} 7$ and 8) which were shaken at $50 \mathrm{rpm}$ in a water-bath at 50 and $60{ }^{\circ} \mathrm{C}$. Samples were withdrawn at various time intervals to measure enzyme activity.

\subsection{Enzyme immobilization}

Alumina pellets (Sigma) were silanised at $45{ }^{\circ} \mathrm{C}$ for $24 \mathrm{~h}$ in a $2.5 \%(\mathrm{v} / \mathrm{v})$ solution of $\gamma$-aminopropyltriethoxy silane (Sigma) in acetone. The silanised pellets were washed with distilled water and immersed in $2 \%(\mathrm{v} / \mathrm{v})$ aqueous glutardialdehyde
(Sigma) for $2 \mathrm{~h}$ at $20{ }^{\circ} \mathrm{C}$. Thereafter, the pellets were incubated with $60 \mathrm{mg}$ protein $1^{-1}$ of the crude enzyme preparation (obtained after ultrasonic treatment of the cells and removal of the cell fragments by centrifugation) for $5 \mathrm{~h}$ at $20{ }^{\circ} \mathrm{C}$. The immobilized enzyme pellets were washed with potassium phosphate buffer (100 mM, pH 7.0) and kept refrigerated until further use. Immobilized protein was determined by protein analysis according to the method of Bradford using BSA for the calibration (Bradford, 1976).

\subsection{Enzymatic treatment of bleaching effluents}

Typically simulated bleaching effluents or 80 mg $1^{-1} \mathrm{H}_{2} \mathrm{O}_{2}$ solutions were continuously pumped $\left(0.1 \mathrm{ml}^{-1} \mathrm{~min}\right.$, dual-piston-pump) through a column $\left(15 \times 300 \mathrm{~mm}^{2}\right)$ filled with $50 \mathrm{ml}$ immobilized catalase corresponding to about 93.000 nkat catalase activity. Both the column reactor and the flow cell were kept at $30{ }^{\circ} \mathrm{C}$ and $\mathrm{H}_{2} \mathrm{O}_{2}$ degradation was monitored on a spectrophotometer equipped with a flow cell.

\subsection{Dyeing experiments}

Cotton fabrics were bleached in a bath containing (\% of weight fabric) silicate 3.5 , soda ash 1 , sodium hydroxide $1,35 \%$ hydrogen peroxide 4 at $90{ }^{\circ} \mathrm{C}$ for $180 \mathrm{~min}$.

The bleaching bath, containing the fabric was treated with either free $\left(93.000 \mathrm{nkat}^{\mathrm{ml}}{ }^{-1}\right)$ or immobilized catalase till all remaining hydrogen peroxide was converted to oxygen and water. Thereafter, the catalase treated liquor was reused for dyeing with Reactive Blue 198-a monochlorotriazine dye- $(3 \%$ o.w.f depth of shade) in the presence of $60 \mathrm{~g}^{-1}$ Glauber's salt and $20 \mathrm{~g} \mathrm{1}^{-1}$ soda ash. Dyeing was performed at $80{ }^{\circ} \mathrm{C}$ for $60 \mathrm{~min}$. Both dyeing and bleaching were carried out in an Ahiba Spectradye dyeing apparatus (Datacolor International, Luzern, Switzerland) at a liquor to good ratio of 20:1 (40 $\mathrm{rpm}$, step 1: temperature was raised from 20 to $80{ }^{\circ} \mathrm{C}$ in $20 \mathrm{~min}$; step 2: $80{ }^{\circ} \mathrm{C}, 60 \mathrm{~min}$ ). Each dyeing experiment was repeated three times. Dyed fabrics were washed-off at the same liquor ratio with non-ionic detergent Lutensol ON-30 for 30 
Table 1

Characteristics of three isolated thermoalkaliphilic Bacillus sp.

\begin{tabular}{llll}
\hline & B. pallidus & Bacillus sp. LF & Bacillus sp. SF \\
\hline Shape & Rods & Rods & Rods \\
Diameter & $0.6-0.9 \mu \mathrm{m}$ & $0.6-0.9 \mu \mathrm{m}$ & $0.6-0.7 \mu \mathrm{m}$ \\
Length & $2-4 \mu \mathrm{m}$ & $2-4 \mu \mathrm{m}$ & $2-5 \mu \mathrm{m}$ \\
Spore formation & + & + & - \\
Catalase activity $\left(\mathrm{nkat} \mathrm{mg}^{-1}\right.$ ) & 8.300 & 63.000 & 107.900 \\
\hline
\end{tabular}

min at $90{ }^{\circ} \mathrm{C}$ to remove the unfixed dye. Diode array spectra (TIDAS instrument from J\&M, Aalen, Germany) of dyes both in standard dye baths and in dye baths containing enzymatically treated bleaching effluents were recorded. Color differences of the dyed fabrics were determined using a reflectance measuring apparatus (Spectraflash 600 from Datacolor) according to the CIELAB color difference concept at standard illuminant $\mathrm{D}_{65}\left(\mathrm{LAV} / \mathrm{Spec}\right.$. Excl., $\left.\mathrm{d} / 8, \mathrm{D}_{65} / 10^{\circ}\right)$ with a color tolerance interval of 1 CIELAB unit.

\section{Results and discussion}

\subsection{Isolated micro-organisms}

Out of a textile finishing effluent, three thermoalkali-stable bacterial strains were isolated. One organism was identified as B. pallidus, while the other two organisms were new representatives of the Bacillus genus. Standard analysis of the cellular fatty acids indicated that all three isolated bacteria belong to thermophilic Bacillus sp. according to the DSMZ database. Similarly, the physiological conditions determined for the organisms clearly pointed to alkalophilic Bacillus sp. in all three cases. Partial sequencing of both the 16S rDNA of Bacillus SF and LF revealed below 92.5\% similarity to other Bacillus sp. while the 16S rDNA of another strain showed $99.1 \%$ similarity to B. pallidus (data not shown). There are only few reports on thermoalkaliphilic species such as Bacillus sp. TAR-1 (Takahashi et al., 2000), B. thermocatenulatus (Rua et al., 1997), Bacillus thermoalcaliphilus (Sarkar and Upadhyay, 1993), or an anaerobic strain LBS3 (Prowe et al., 1996).

\subsection{Catalases from the Bacillus sp.}

B. pallidus, Bacillus LF and SF were cultivated in a 101 Bioreactor and crude enzyme preparations were obtained showing catalase activities of $8.300,63.000$ and $107.900 \mathrm{nkat}^{\mathrm{mg}}{ }^{-1}$, respectively (Table 1). The catalases of all three strains were quite stable at $\mathrm{pH} 10$ and $25^{\circ} \mathrm{C}$, showing halflives of at least 1 day (Table 2). Interestingly, at this temperature, all catalases showed substantially higher stabilities at $\mathrm{pH} 8$ than at $\mathrm{pH}$ 7. At higher temperatures, the catalases of Bacillus SF were more stable than the enzymes from $B$. pallidus and Bacillus LF. At $60{ }^{\circ} \mathrm{C}$, the Bacillus SF catalases had 13 and 10 times longer half-lives than the catalases from B. pallidus and Bacillus LF, respectively. Therefore, this strain and its enzymes were chosen for all further investigations.

Although catalases, which are produced by most aerobic micro-organisms are very well stud-

Table 2

Half-life $t_{1 / 2}(\mathrm{~h})$ of catalases from three thermoalkaliphilic Bacillus sp.

\begin{tabular}{lrccc}
\hline Strain & $\mathrm{pH}$ & $25{ }^{\circ} \mathrm{C}$ & $50{ }^{\circ} \mathrm{C}$ & $60{ }^{\circ} \mathrm{C}$ \\
\hline B. pallidus & 7.0 & 48 & 3 & 3 \\
& 8.0 & 96 & 3 & 4 \\
& 9.0 & 96 & 4 & 3 \\
Bacillus sp. LF & 10.0 & 48 & 1 & 1 \\
& 7.0 & 48 & 5 & 1 \\
& 8.0 & 72 & 6 & 3 \\
& 9.0 & 48 & 7 & 2 \\
Bacillus sp. SF & 10.0 & 24 & 3 & 0.5 \\
& 7.0 & 216 & 15 & 22 \\
& 8.0 & 240 & 20 & 42 \\
& 9.0 & 240 & 48 & 38 \\
& 10.0 & 148 & 15 & 4 \\
\hline
\end{tabular}




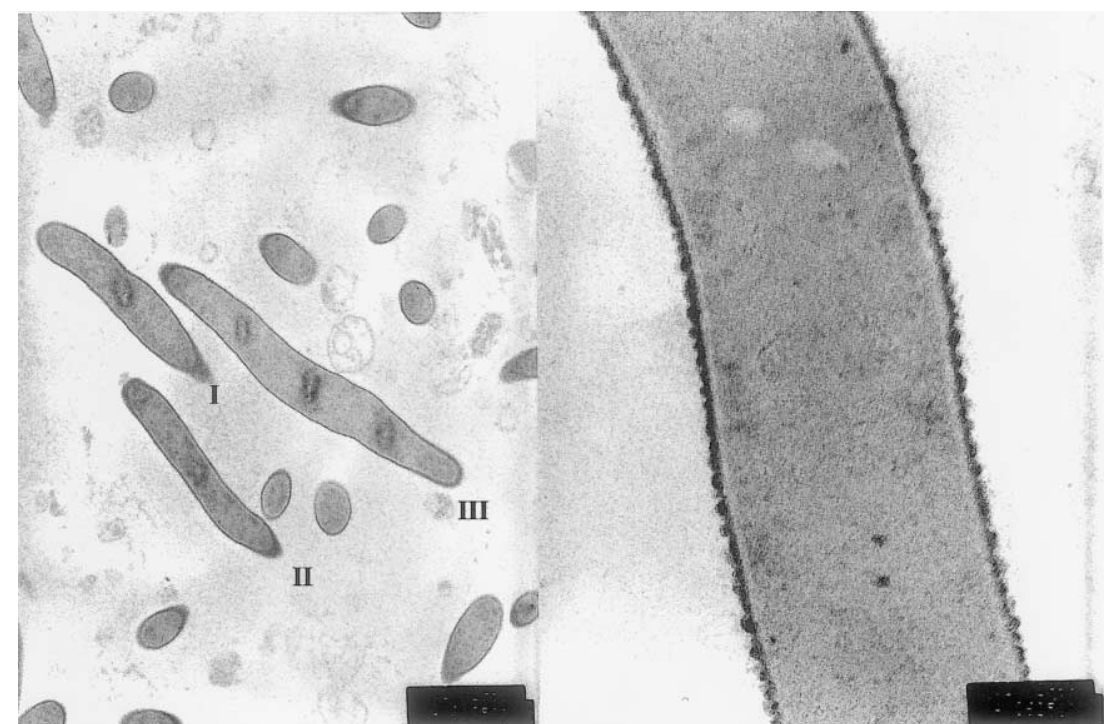

(a)

(b)

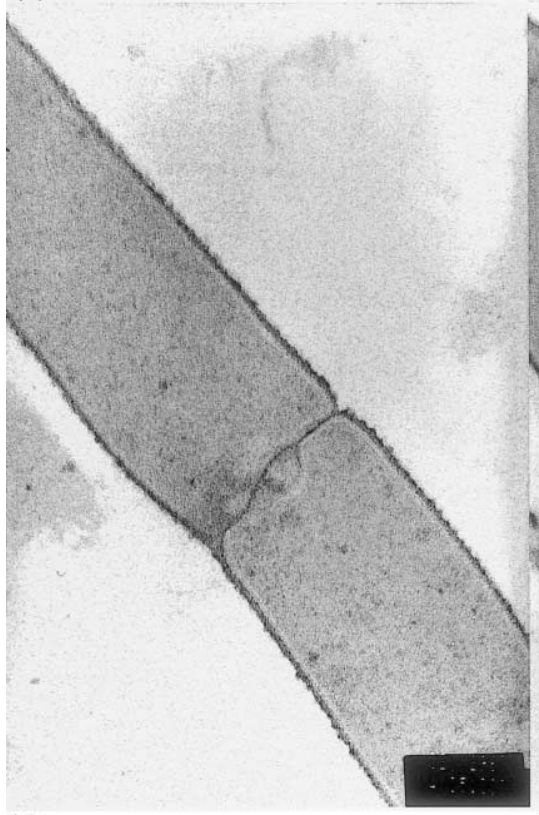

(c)

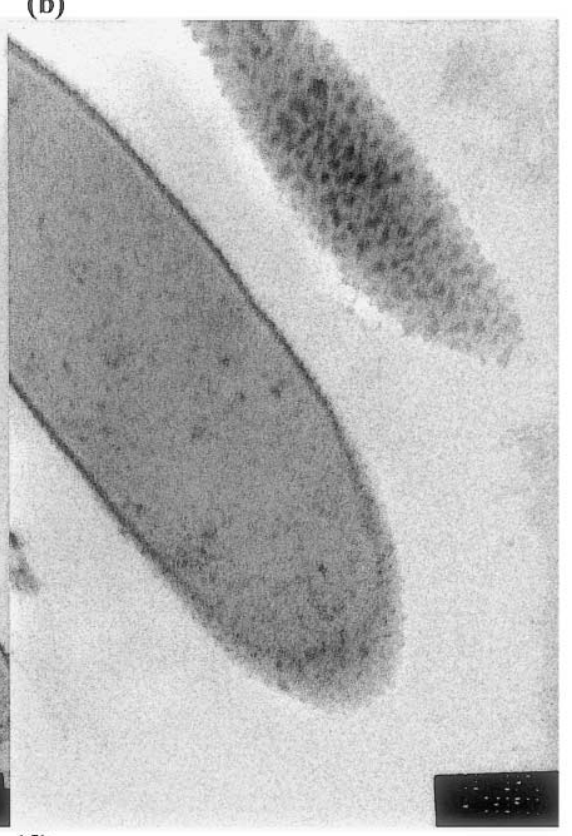

(d)

Fig. 1. Electron micrographs of cell walls of Bacillus sp. SF. Magnification: (a) 10.500; (b) 62.500; (c) 51.000; and (d) 62.500.

ied enzymes, there are only very few reports on thermo and/or alkali-stable catalases. Purified Thermoleophilum album catalase has its activity maximum at $35{ }^{\circ} \mathrm{C}$ with $56 \%$ of this activity at $60{ }^{\circ} \mathrm{C}$, but retains $90 \%$ of its initial activity after incubation for $1 \mathrm{~h}$ at $80{ }^{\circ} \mathrm{C}$ and $93 \%$ activity after incubation for $24 \mathrm{~h}$ at $60{ }^{\circ} \mathrm{C}$. This catalase retains $100 \%$ activity after $3 \mathrm{~h}$ of incubation at $25^{\circ} \mathrm{C}$ in buffers over a range of 6.5-11.0 (Allgood and Perry, 1986). 


\subsection{Bacillus $S F$}

Bacillus SF was studied under the electron microscope. Fig. 1(b) shows a cell wall with an ordered structure, which can also be seen from the surface (Fig. 1(d)). A number of micro-organisms show ordered structures such as S-layers which have been studied extensively (Taylor et al., 1982; Olabarria et al., 1996). However, the nature of the ordered layer of Bacillus SF remains to be investigated. The cell wall of Bacillus SF seems to be very thick (1b). Indeed, with a thickness of $18.6+/-2.5 \mathrm{~nm}$ it was comparable to that of the alkalophilic Bacillus lentus $(21.5+/-2.2 \mathrm{~nm})$ (Aono et al., 1995), but it was thicker than the cell wall of a thermophilic Claderobacterium hydrogenophilum with a thickness of 9-10 nm (Ludvik et al., 1994). Since the cell walls of alkaliphilic Bacilli is thought to be essential in providing a passive barrier to ion flux and elevation of cytoplasmic buffering capacity at highly alkaline growth $\mathrm{pH}$ (Krulwich et al., 1997), a thick cell wall with unusual shape of the new Bacillus SF is not surprising. Examination of the dark hemispherical structures in the cells (Fig. 1(a) - I, II and III) are most likely artefacts resulting from separation of the cytoplasm during the fixation of the cells.

\subsection{Catalase immobilization, treatment and recycling of bleaching effluents}

To allow repeated treatment of bleaching effluents, catalase preparations of Bacillus SF was immobilized. Preliminary experiments using glass-foam pellets as a support material were not successful because of the instability of glassfoam at high $\mathrm{pH}$. On alumina, 93\% of the enzyme protein in the catalase preparation was bound to the pellets and $87 \%$ of the activity was retained. This carrier material has recently been used for the immobilization of a laccase for the decolorization of textile dyeing effluents (Abadulla et al., 2000). The activity of the immobilized catalase was measured in an enzyme reactor monitoring continuously the difference between the $\mathrm{H}_{2} \mathrm{O}_{2}$ concentration in the influent and in the effluent. With this system, $\mathrm{H}_{2} \mathrm{O}_{2}$ was continuously degraded in a bleaching bath, which was further used for dyeing.

To compare the effect of free and immobilized catalase in the re-dyeing process, the shift of the co-ordinates of the color in the cylindrical color space $\mathrm{L} *, \mathrm{a} *$ and $\mathrm{b} *$, based on the theory that color is perceived by black-white (L), red-green (a) and yellow-blue (b) sensations (Harold, 1987), was summarized by the $\Delta E *$ value. The value of $\Delta E *$ represents the overall color difference between the sample and the standard (Table 3). Correlation between absorbance measurement in solution and reflectance measurements on dyed fabrics was evident (Ericson and Posner, 1996). Compared to the free catalase, the use of immobilized catalase for the treatment of bleaching baths gave a substantially lower $\Delta E *$ value in the dyeing process (Table 3 ). This indicated that the protein from the free enzyme might somehow interact with the dyeing process giving a larger color difference to a blank using water instead of enzymatically treated bleaching effluent for the preparation of the dyeing bath. Similar findings have been reported previously for laccase catalyzed decolorization of dyeing effluents, where enzyme protein had interacted with the re-dyeing process (Abadulla et al., 2000).

The $\Delta E *$ values for re-dyeing with bleaching baths treated with the immobilized catalase were around 1.0, which is acceptable to the industry (Baumann et al., 1987; Harold, 1987; Steen, 1998). However, these values might certainly be improved by proper adjustments of the standard dyeing protocols.

Table 3

Color difference between fabrics dyed in dyebaths prepared with water and fabrics dyed in dyebaths prepared with catalase treated bleaching liquor

\begin{tabular}{lll}
\hline & $\Delta E^{*}$ & Standard deviation \\
\hline Free catalase & 1.264 & 0.034 \\
Immobilized catalase & 0.886 & 0.022 \\
\hline
\end{tabular}




\section{Acknowledgements}

We thank Dr Elisabeth Ingolic, Forschungsinstitut für Elektronenmikroskopie und Feinstrukturforschung, Graz University of Technology, for assisting with the electron microscopy, and the European Commission for financial support of the project EW 980009 .

\section{References}

Abadulla, E., Tzanov, T., Costa, S., Robra, K.-H., CavacoPaulo, A., Gübitz, G.M., 2000. Decolorization and detoxification of textile dyes with a laccase from Trametes hirsuta. Appl. Environ. Microbiol. 66, 3357-3362.

Aebi, H.E., 1983. Catalase. In: Bergmeyer, H.U. (Ed.), Methods of Enzymatic Analysis, vol. 3. Verlag Chemie, Weinheim, pp. 273-286.

Allgood, G.S., Perry, J.J., 1986. Characterization of a manganese-containing catalase from the obligate thermophile Thermoleophilum album. J. Bacteriol. 168 (2), 563-567.

Aono, R., Ito, M., Joblin, K.N., Horikoshi, K., 1995. A high cell wall negative charge is necessary for the growth of the alkaliphile Bacillus lentus $\mathrm{C}-125$ at elevated $\mathrm{pH}$. Microbiology 141, 2955-2964.

Baumann, W., Brossmann, R., Groebel, B.T., Kleinemeier, N., Krayer, M., Leaver, A.T., Oesch, H.P., 1987. Determination of relative color strength and residual color difference by means of reflectance measurements. Part II. Determination of residual color difference. Text. Chem. Color. 19, $21-22$.

Berkeley, R.C., Goodacre, R., 1992. Identification of some common Bacillus thermophiles using the API system and a microcomputer. In: Board, R.G., Jones, D., Skinner, F.A. (Eds.), Iden. Meth. Appl. Environ. Microbiol., Blackwell Sci. Pub., Oxford, UK, pp. 251-256.

Bradford, M., 1976. A rapid and sensitive method for the quantification of microgram quantities of protein utilizing the principle of protein-dye binding. Anal. Biochem. 72, $248-254$.

Chatterjee, U., Kumar, A., Sanwal, G.G., 1990. Goat liver catalase immobilized on various solid supports. J. Ferment. Bioeng. 70, 429-430.

Ericson, A.C., Posner, S., 1996. Relative absorbance and reflectance measurements of dye solutions and dyed fabrics. Text. Chem. Color. 28, 23-27.

Gekas, V.C., 1986. Artificial membranes as carriers for the immobilization of biocatalysts. Enzyme Microb. Technol. 8, 450-460.

Harold, R.W., 1987. Textiles: appearance analysis and shade sorting. Text. Chem. Color. 19, 23-31.
Hillenbrand, T., 1999. Die Abwassersituation in der deutschen Papier-, Textil- und Lederindustrie. Gwf. Wasser Abwasser 140 (4), 267-273.

Horozova, E., Dimcheva, N., Jordanova, Z., 1997. Adsorption, catalytic and electrochemical activity of catalase immobilized on carbon materials. Z. Naturforsch. C. 52, 639-644.

Krulwich, T.A., Guffanti, A.A., 1989. Alkalophilic bacteria. Annu. Rev. Microbiol. 43, 435-463.

Krulwich, T.A., Ito, M., Gilmour, R., Guffanti, A.A., 1997. Mechanisms of cytoplasmic $\mathrm{pH}$ regulation in alkaliphilic strains of Bacillus. Extremophiles 1, 163-169.

Loew, O., 1901. US Dept. Agr. Report. (68), 68, pp. 47-55.

Loewen, P.C., Klotz, M.G., Hassett, D.J., 2000. Catalase an 'old' enzyme that continues to surprise us. Asm News 66, $76-82$.

Ludvik, J., Benada, O., Mikulik, K., 1994. Ultrastructure of an extreme thermophilic hydrogen oxidizing bacterium Calderobacterium hydrogenophilum. Arch. Microbiol., 267271.

Michaudsoret, I., Jacquamet, L., Debaeckerpetit, N., Lepape, L., Barynin, V.V., Latour, J.M., 1998. The existence of 2 oxidized $\mathrm{Mn}$ (III)Mn(III) forms of Thermus thermophilus manganese catalase. Inorg. Chem. 37, 3874-3876.

Nakamura, S., Ishiguro, Y., Nakai, R., Wakabayashi, K., 1995. Purification and characterization of a thermophilic alkaline xylanase from thermophilic Bacillus sp. strain TAR-1. J. Mol. Catal. B: Enymatic 1, 7-15.

Olabarria, G., Carrascosa, J.L., Pedro, M.A., Berenguer, J., 1996. A conserved motif in S-layer proteins is involved in peptidoglycan binding in Thermus thermophilus. J. Bacteriol. 178 (16), 4765-4772.

Prowe, S.G., van de Vossenberg, J.L., Driessen, A.J., Antranikian, G., Konings, W.N., 1996. Sodium-coupled energy transduction in the newly isolated thermoalkaliphilic strain LBS3. J. Bacteriol. 178 (14), 4099-4104.

Rua, M.L., Schmidt-Dannert, C., Wahl, S., Sprauer, A., Schmid, R.D., 1997. Thermoalkalophilic lipase of Bacillus thermocatenulatus large-scale production, purification and properties: aggregation behavior and its effect on activity. J. Biotechnol. 56 (2), 89-102.

Sarkar, A., Upadhyay, S.N., 1993. Purification and characterization of cellulase from Bacillus thermoalcaliphilus isolated from a termit mound. Fol. Microbiol. 38 (1), 29-32.

Steen, D., 1998. Acceptabilité colorimétrique, comparaison des équations CMC et CIE94. L'Industrie Textile 1300, 55-58.

Sumner, J.B., Dounce, A.L., 1937. Crystalline catalase. J. Biol. Chem. 121, 417-424.

Takahashi, H., Nakai, R., Nakamura, S., 2000. Purification and partial characterization of a basic xylanase produced by thermoalkalophilic Bacillus sp. strain TAR-1. Biosci. Biotechnol. Biochem. 64 (4), 887-890.

Taylor, K.A., Deatherage, J.F., Amos, L.A., 1982. Structure of the S-layer of Sulfolobus acidocaldarius. Nature 299, $840-842$.

Wiegel, J., 1998. Anaerobic alkalithermophiles, a novel group of extremophiles. Extremophiles 2, 257-267. 